\title{
FORMULASI SEDIAAN SABUN PELEMBAB TRANSPARAN YANG MENGANDUNG MINYAK BIJI BUNGA MATAHARI (Sunflowerseed Oil)
}

\author{
Gayatri Simanullang*1, Ahmad Ngadeni ${ }^{2}$, Titta Hartyana ${ }^{2}$ \\ ${ }^{1}$ Program Studi Farmasi, Jurusan Sains, Institut Teknologi Sumatera \\ ${ }^{2}$ Program Studi Farmasi, Fakultas Farmasi, Universitas Jenderal Achmad Yani \\ *Email: gayatrisimanullang@gmail.com
}

Received: 28/01/2021, Revised: 23/02/2021, Accepted: 25/02/2021, Published: 28/02/2021

\begin{abstract}
ABSTRAK
Minyak biji bunga matahari mengandung vitamin $\mathrm{E}$ yang dapat dimanfaatkan untuk industri farmasi, termasuk kosmetik. Telah dilakukan penelitian mengenai formulasi sediaan sabun pelembab transparan yang mengandung minyak biji bunga matahari dengan berbagai konsentrasi minyak biji bunga matahari $(0,5,10,15 \% \mathrm{~b} / \mathrm{b})$. Penelitian ini bertujuan untuk membuat formulasi sediaan sabun pelembab transparan dengan berbagai konsentrasi minyak biji bunga matahari (Sunflowerseed Oil) untuk melembabkan dan melembutkan kulit. Penelitian dilakukan dengan mengamati stabilitas fisik sediaan sabun pelembab transparan yang meliputi stabilitas fisik sediaan sabun pelembab transparan yang meliputi stabilitas fisika (organoleptis, homogenitas), uji stabilitas kimia $(\mathrm{pH})$, dan pengujian terhadap sukarelawan menggunakan alat Skin Analyzer. Hasil penelitian menunjukkan bahwa sediaan sabun pelembab transparan mulai memberikan efektivitas melembabkan pada formula yang mengandung minyak biji bunga matahari 5\% (F1) dan pada formula F2 (10\%) merupakan formula yang paling disukai karena nyaman dalam penggunaannya. Hasil penelitian juga menunjukkan bahwa sediaan sabun pelembab transparan dengan konsentrasi 5\%, 10\% dan 15\% aman digunakan.
\end{abstract}

Kata kunci : minyak biji bunga matahari, sabun transparan, skin analyzer

\begin{abstract}
Sunflowerseed oil contains vitamin $E$ which can be used for the pharmaceutical industry, including cosmetics. Research on the formulation of transparent moisturizing soap containing sunflowerseed oil with various concentration of sunflowerseed oil $(0,5,10,15 \%$ w/w) has been conducted. This study aims to make a transparent moisturizing soap formulation with various concentration of sunflowerseed oil to moisturize and soften the skin. The research was conducted by observing the physical stability of transparent moisturizing soap preparations which included the physical stability of transparent moisturizing soap preparations which included physical stability (organoleptic, homogeneity), chemical stability test ( $p H$ ), and testing of volunteers using a Skin Analyzer. The results showed that transparent moisturizing soap preparations began to provide moisturizing effectiveness in formula containing sunflowerseed oil 5\% (F1) and formula F2 (10\%) was the most preferred formula because it was comfortable
\end{abstract}


to use. The results also showed that transparent moisturizing soap preparations with a concentration of 5\%,10\% and $15 \%$ were safe to use.

Keywords: skin analyzer, sunflowerseed oil, transparent soap

\section{PENDAHULUAN}

Kulit merupakan organ tubuh esensial dan vital, yang terletak paling luar dan berfungsi untuk melindungi terhadap pengaruh lingkungan. Untuk luas kulit dewasa sekitar $1,5 \mathrm{~m}^{2}$ dengan berat $15 \%$ berat badan (Djuanda, 2007). Kelenturan dan fungsi kulit sebagai pelindung sangat dipengaruhi oleh kelembaban kulit. Pada stratum korneum, kelembaban normal terdapat kandungan air sekitar 15-20\%. Kelembaban lapisan korneum ditentukan oleh kecepatan kehilangan air dan kecepatan peningkatan kandungan air. Hilangnya air pada lapisan epidermal (Transepidermal Water Loss) disebabkan difusi air secara terus menerus didalam tubuh melalui stratum korneum ke lingkungan (Ditjen POM, 2004). Untuk mengatasi pengaruh kelembaban udara terhadap kulit dapat digunakan kosmetika pelembab kulit yang mengandung emolien.

Emolien adalah suatu bahan yang digunakan untuk mencegah, mengurangi serta melindungi kulit serta kekeringan. Emolien yang biasanya digunakan untuk melembabkan kulit yaitu berasal dari alam, salah satunya dari minyak biji bunga matahari.

Minyak biji bunga matahari (Sunflowerseed oil) adalah minyak lemak yang diperoleh dari biji bunga matahari (Helianthus annuus) dan merupakan minyak alami yang menyehatkan. Kandungan yang terdapat didalam minyak biji bunga matahari yaitu lemak tak jenuh yang tinggi, rendah kolesterol dan vitamin-vitamin. Vitamin dengan antioksidan yang tinggi dalam minyak biji bunga matahari mampu menghambat radikal bebas yang merusak sel kulit dan melembabkan kulit.

Berdasarkan uraian tersebut diatas, peneliti membuat sediaan kosmetika pelembab berupa sabun pelembab transparan yang mengandung minyak biji bunga matahari. Sediaan sabun transparan merupakan salah satu inovasi sabun padat agar terlihat lebih menarik dan memiliki busa yang lebih lembut jika dibandingkan dengan sabun yang tidak transparan (Hildianti, 2016) sehingga dapat memudahkan dan memaksimalkan penggunaan. Selain itu, untuk mendapatkan hasil sediaan sabun dengan kualitas yang 
baik, harus menggunakan bahan baku dengan kualitas yang baik pula (Widyasanti dkk., 2016).

Tujuan penelitian ini yaitu untuk membuat formulasi sediaan sabun pelembab transparan yang mengandung minyak biji bunga matahari dibuat dengan konsentrasi $0 \%, 5 \%, 10 \%$, dan $15 \%$.

\section{METODE PENELITIAN}

\section{Alat dan Bahan}

Bahan yang digunakan selama penelitian yaitu minyak biji bunga matahari (Sunflowerseed oil) dari CV. Bakti Megah Abadi (Gambar 1), oleum cocos (Pharmaceutical Grade, Brataco), asam stearate (Pharmaceutical Grade, Brataco), natrium hidroksida (Pharmaceutical Grade, Brataco), gliserin (Pharmaceutical Grade, Brataco), sukrosa (Pharmaceutical Grade, Brataco), asam sitrat (Pharmaceutical Grade, Brataco), etanol 95\% (Pharmaceutical Grade, Brataco), BHT (Pharmaceutical Grade, Brataco), coco Dea (Pharmaceutical Grade, Brataco), pewangi oleum lido (Pharmaceutical Grade, Brataco) dan air suling.

Alat yang digunakan dalam penelitian adalah alat-alat gelas yang umum digunakan di laboratorium, kaki tiga, Bunsen, thermometer, botol semprot, buret 12
$25 \mathrm{~mL}$, timbangan analitik (Sartorius BL 210 S), hot plate, cetakan sabun, $\mathrm{pH}$ meter (Boeco), piknometer $25 \mathrm{~mL}$ (Scott duran), Karl Fischer dan Skin Analyzer (HL 610).

\section{Jalannya Penelitian}

1. Pemeriksaan Bahan Baku

Pemeriksaan minyak biji bunga matahari dilakukan uji organoleptis (warna, bau, dan rasa), penentuan kadar air, penentuan berat jenis, penentuan bilangan asam, penentuan bilangan penyabunan, penentuan bilangan iod, dan penentuan bilangan ester (BSN, 1998).

\section{a. Uji Organoleptis \\ Pemeriksaan warna (Diteteskan} sebanyak $2 \mathrm{ml}$ minyak biji bunga matahari ke dalam tabung reaksi kemudian diamati warnanya ditempat terang), bau (Diteteskan minyak biji bunga matahari pada selembar kertas saring kemudian disimpan didepan hidung untuk beberapa lama) (BSN, 1998).

\section{b. Penentuan Kadar Air \\ Pengukuran kandungan air dengan} metode titrasi standar menggunakan alat Karl Fischer. Titrasi menggunakan iodine dalam metanol sebagai titran dan imidazol, sulfur dioksida, metanol sebagai 
solvent (pelarut). Zat yang diperiksa dimasukkan ke dalam wadah melalui pipa pengalir yang dapat disumbat. Kemudian kadar air dapat dilihat dalam monitor titrator Karl Fischer.

\section{c. Penentuan Bobot Jenis}

Air suling yang telah dididihkan dan didinginkan pada suhu 20-23 ${ }^{\circ} \mathrm{C}$ dimasukkan ke dalam piknometer $25 \mathrm{~mL}$, kemudian ditutup dan direndam dalam air dengan suhu $25 \pm 0,2{ }^{\circ} \mathrm{C}$ selama 30 menit. Lalu dengan hati-hati piknometer diangkat dari bak air. Piknometer ditimbang dengan isinya (sampel). Bobot air adalah selisih bobot piknometer dengan isinya dikurangi bobot piknometer kosong. Selanjutnya dengan prosedur yang sama sampel minyak biji bunga matahari (Sunflowerseed Oil) dimasukkan ke dalam piknometer dan ditimbang (BSN, 1998).

$$
\text { Bobot Jenis }=\frac{\mathrm{W} 2-\mathrm{Wo}}{\mathrm{W} 1}
$$

\section{Keterangan :}

Wo $=$ bobot piknometer kosong.

$\mathrm{W} 1$ = bobot piknometer isi air.

$\mathrm{W} 2=$ bobot piknometer isi minyak biji bunga matahari. d. Penentuan Bilangan Asam

$$
\text { Penentuan bilangan asam }
$$

dilakukan berdasarkan BSN (1998)

metode titrasi, dengan menggunakan rumus :

$$
\text { Bilangan asam }=\frac{\mathrm{V} \times \mathrm{N} \times 56,1}{\mathrm{~m}}
$$

Keterangan :

$V$ adalah volume $\mathrm{KOH}$ yang diperlukan dalam peniteran.

$N$ adalah normalitas $\mathrm{KOH}$.

$m$ adalah bobot minyak biji bunga matahari.

56,1 adalah bobot molekul $\mathrm{KOH}$.

e. Penentuan Bilangan Penyabunan

Penentuan bilangan penyabunan dilakukan berdasarkan BSN (1998) metode titrasi, dengan menggunakan rumus :

Bil. Penyabunan $=\frac{56,1 \times \mathrm{N} \times(V o-V 1)}{\mathrm{m}}$

\section{Keterangan:}

$V_{o}$ adalah volume $(\mathrm{mL}) \mathrm{HCl} 0,5 \mathrm{~N}$ yang diperlukan pada peniteran blanko.

$V_{1}$ adalah volume $(\mathrm{mL}) \mathrm{HCl} 0,5 \mathrm{~N}$ yang diperlukan pada peniteran minyak biji bunga matahari.

$N$ adalah normalitas $\mathrm{HCl} 0,5 \mathrm{~N}$.

$m$ adalah bobot minyak biji bunga matahari (gram).

56,1 merupakan berat molekul KOH. 


\section{f. Penentuan Bilangan Iod}

Penentuan bilangan iod dilakukan berdasarkan BSN (1998) metode titrasi, dengan menggunakan rumus :

$$
\text { Bilangan iod }=\frac{(V o-V 1) \times \mathrm{N} \times 12.69}{\mathrm{~m}}
$$

Keterangan:

$V_{o}$ adalah volume $(\mathrm{mL})$ natrium tiosulfat 0,1 N LV yang diperlukan pada peniteran blanko.

$V_{l}$ adalah volume $(\mathrm{mL})$ natrium tiosulfat 0,1 N LV yang diperlukan pada peniteran minyak biji bunga matahari.

$N$ adalah normalitas $\mathrm{Na}$ Tiosulfat $0,1 \mathrm{~N}$. $m$ adalah bobot minyak biji bunga matahari (gram).

\section{g. Penentuan Bilangan Ester}

Bilangan ester $=$ bilangan penyabunan - bilangan asam (BSN, 1998).

2. Pembuatan Sabun Pelembab Transparan Yang Mengandung Minyak Biji Bunga Matahari (Sunflowerseed oil)

Formulasi sediaan sabun pelembab transparan dapat dilihat pada Tabel 1 yaitu menggunakan kombinasi antara minyak kelapa (oleum cocos) dan minyak biji bunga matahari dengan berbagai konsentrasi. Bahan-bahan dipersiapkan dan ditimbang terlebih dahulu. Fase minyak, yaitu asam stearat dilebur pada suhu $60^{\circ} \mathrm{C}$ selama 15 menit, kemudian ditambahkan minyak kelapa dan minyak biji bunga matahari serta BHT, diaduk hingga homogen dan merata. Jika suhu sudah mencapai $70^{\circ}-80^{\circ} \mathrm{C}$ ditambahkan $\mathrm{NaOH}$ sebagai fase basa dan diaduk selama 2-4 menit (penyiapan stok sabun). Gliserin ditambahkan perlahan-lahan, diikuti dengan penambahan sukrosa, asam sitrat, etanol, dan air. Pengadukan terus dilakukan hingga campuran menjadi homogen sekitar 7-10 menit. Khusus untuk bahan pewangi ditambahkan pada suhu $40^{\circ} \mathrm{C}$ karena dikhawatirkan pada suhu yang lebih tinggi dapat menyebabkan pewangi menguap saat dituangkan sehingga kehilangan pewangi yang cukup besar akan terjadi. Campuran dituangkan ke dalam cetakan dan diamkan selama 24 jam hingga sabun mengeras. Sabun pelembab transparan yang telah mengeras kemudian dikeluarkan dari cetakan.

3. Evaluasi Sediaan Sabun Pelembab Transparan Yang Mengandung Minyak Biji Bunga Matahari (Sunflowerseed oil) 
a. Pemeriksaan Organoleptis dan Homogenitas

Setiap sediaan sabun dilihat tekstur fisik yang baru dibuat dan yang telah disimpan selama 7, 14, 21, dan 28 hari. Diamati bau, bentuk, warna, dan homogenitas dari masing-masing sediaan.

\section{b. Pengukuran $\mathrm{pH}$}

Disiapkan alat $\mathrm{pH}$ meter yang telah dikalibrasi. Bagian ujung elektroda $\mathrm{pH}$ meter yang akan dicelupkan dalam sampel dibersihkan menggunakan air suling dan dilap menggunakan tisu hingga bersih dan kering. Elektroda $\mathrm{pH}$ meter kemudian dicelupkan ke dalam sabun yang telah dilarutkan di dalam air suling pada beaker glass. Hasil pH dapat dibaca pada layar alat $\mathrm{pH}$ meter.

\section{c. Kadar Air}

Pengukuran kandungan air dengan metode titrasi standar menggunakan alat Karl Fischer. Titrasi menggunakan iodine dalam metanol sebagai titran dan imidazol, sulfur dioksida, metanol sebagai solvent (pelarut). Zat yang diperiksa dimasukkan ke dalam wadah melalui pipa pengalir yang dapat disumbat. Kemudian kadar air dapat dilihat dalam monitor titrator Karl Fischer.

\section{d. Analisa Asam Lemak Bebas}

Sediaan $5 \mathrm{~g}$ ditambahkan ditambahkan $50 \mathrm{~mL}$ etanol 95\%, panaskan di atas penangas air sampai mendidih dan dibiarkan mendidih selama 30 menit lalu dinginkan. Kemudian tambahkan 3 tetes indikator PP, titrasi dengan larutan $0,1 \mathrm{~N}$ $\mathrm{NaOH}$ sampai warna merah tidak hilang. Hasilnya kemudian dihitung sebagai asam laurat (BSN, 1994).

$$
\text { Asam lemak bebas }=\frac{\mathrm{mL} \times \mathrm{N} \times 0,205}{\mathrm{~g} \text { sampel }}
$$

Keterangan :

$205=$ berat setara asam laurat.

$\mathrm{mL} \quad=$ volume natrium hidroksida yang dipergunakan.

$\mathrm{N} \quad=$ normalitas $\mathrm{NaOH}$ yang dipergunakan.

e. Analisa Bilangan Penyabunan

Ditimbang seksama 2 gram sediaan dalam labu $200 \mathrm{~mL}$, tambahkan $25 \mathrm{~mL}$ larutan kalium hidroksida etanol 0,5 N. Refluks di atas tangas air selama 1 jam sambil sering digoyang. Titrasi selagi panas dengan asam klorida $0,5 \mathrm{~N}$ menggunakan indikator $1 \mathrm{~mL}$ larutan fenoltalein $P$. Lakukan penetapan 
bilangan blangko. Hitung dengan rumus (BSN, 1994) :

$$
\text { Bilangan penyabunan }=\frac{(\mathrm{b}-\mathrm{a}) \times 20}{\mathrm{~g} \text { sampel }}
$$

\section{Dimana :}

a = jumlah ml $\mathrm{HCl} 0,5 \mathrm{~N}$ yang diperlukan untuk titrasi zat uji.

$\mathrm{b} \quad=$ jumlah $\mathrm{ml} \mathrm{HCl} 0,5 \mathrm{~N}$ yang diperlukan untuk titrasi blangko.

g = bobot dalam gram zat uji.

$20=$ harga jumlah massa setengah mol Natrium Hidroksida.

\section{f. Uji Iritasi}

Uji ini dilakukan terhadap 10 sukarelawan untuk mencegah terjadinya efek samping iritasi pada kulit yang timbul ketika penggunaan seperti kemerahan (eritema), kulit mengelupas, dan reaksi gatal, maka sukarelawan dapat melakukan uji pakai (usage test) di tempat lain, yaitu memakai sediaan kosmetik dengan cara yang biasa dipakai seharihari, setelah itu dibiarkan selama 3 hari. Jika tidak terjadi reaksi iritasi pada kulit maka sediaan kosmetik tersebut aman digunakan (Tranggono dan Latifah, 2007).

\section{g. Uji Efektivitas (Alat Skin Analyzer)}

Uji ini dilakukan terhadap 24 sukarelawan dengan cara mencuci tangan sebelah kanan dan kiri dengan menggunakan sabun pelembab transparan menggunakan minyak biji bunga matahari dengan berbagai konsentrasi. Pengujian dan pengamatan dilakukan dalam rentang waktu 28 hari utuk melihat perubahan sebelum dan sesudah pemakaian sediaan sabun tersebut. Kriteria sukarelawannya adalah wanita dengan berbagai kondisi kulit dari kering hingga normal, terutama yang memiliki struktur kulit kasar dan agak gelap. Waktu pemakaian minimal sehari dua kali atau tiap kali mencuci tangan. Kulit sukarelawan tidak luka dan selama penggunaan sabun tidak boleh menggunakan produk lain. Parameter pengujian meliputi derajat kelembaban (moist), kandungan minyak pada kulit (oil), dan kekasaran kulit (rough). Pengamatan dilalukan pada punggung tangan sukarelawan. Punggung tangan sukarelawan diukur pada saat sebelum dan sesudah penggunaan sediaan sabun (Gita L, 2010).

\section{h. Uji Kesukaan}

Uji penerimaan sukarelawan dilakukan terhadap 10 sukarelawan, meliputi uji kesukaan terhadap kulit dari berbagai formula sediaan yang diberikan, pengujian ini dilakukan dengan tujuan 
mencari formula yang tepat dari sediaan sabun pelembab transparan yang mengandung minyak biji bunga matahari berdasarkan pendapat sukarelawan dari segi banyaknya busa yang dihasilkan dan tingkat kenyamanan. Sukarelawan diharuskan memakai empat formula sediaan sabun pelembab transparan tersebut pada tangan sebelah kanan dan kiri dengan formula sediaan yang berbeda selama \pm 15 menit. Setelah pemakaian tangan dibilas dengan air hingga bersih. Selanjutnya sukarelawan memberikan penilaian pada tiap formula berdasarkan kenyamanan pemakaian sediaan terhadap kulit sukarelawan (Gita L, 2010).

\section{Analisis Data}

Untuk hasil pengujian efektivitas dan kesukaan (hedonik) yang didapat kemudian diuji secara statistik menggunakan metode uji $\mathrm{t}$ berpasangan dengan tingkat kepercayaan 95\% $(\alpha=$ $0,05)$.

\section{HASIL DAN PEMBAHASAN}

\section{Pemerikasaan Bahan Baku}

Untuk pemeriksaan awal bahan baku pembuatan sabun pelembab transparan meliputi pemeriksaan organoleptis (pemerian, warna, bau, rasa), bobot jenis, kadar air, bilangan asam, bilangan penyabunan, bilangan iod dan bilangan ester dapat dilihat pada Tabel 2 . Pemeriksaan ini dilakukan untuk memastikan bahwa bahan baku yang digunakan sesuai dengan yang diharapkan (tidak berbau tengik, tidak mengalami perubahan warna) dan memiliki kualitas yang baik. Hasil yang diperoleh dari pemeriksaan bahan baku di atas telah memenuhi persyaratan.

2. Pemeriksaan Organoleptis dan Homogenitas

Pengamatan secara organoleptis yang meliputi pengamatan warna dan bau, bertujuan untuk melihat stabilitas dari sediaan sabun pelembab transparan dapat dilihat pada Tabel 3. Dari pengamatan tersebut didapatkan bahwa semakin besar kandungan minyak biji bunga matahari dalam sediaan maka warna sediaan semakin kuning dan tingkat transparansinya pun berkurang (Gambar 2) dan bentuk sabun yang dihasilkan bervariasi dengan tujuan untuk memudahkan membedakan antar formula F0, F1, F2, F3 ketika dilakukan uji evaluasi sediaan dan untuk memberikan 
daya tarik pengguna. Dengan pemberian pewangi ternyata bau tidak menyenangkan baik dari zat aktif minyak biji bunga matahari maupun dari minyak kelapa dapat ditutupi sehingga sediaan sabun memiliki aroma yang wangi. Hasil uji organoleptis, warna dan bau selama 28 hari menunjukkan keempat formula yaitu F0, F1, F2 dan F3 tidak mengalami perubahan baik warna maupun bau. Setelah dikemas pun sediaan tetap kering dan tidak menjadi lembab.

\section{Pengukuran $\mathrm{pH}$}

Berdasarkan data evaluasi $\mathrm{pH}$ selama 28 hari menunjukkan bahwa tidak terjadi perubahan $\mathrm{pH}$ secara drastis dalam setiap sediaan formulasi sabun dan hasil dapat dilihat pada Tabel 4. Nilai pH merupakan karakteristik yang sangat penting dalam menentukan mutu sabun. Sabun yang baik memiliki $\mathrm{pH}$ yang tidak jauh dari $\mathrm{pH}$ kulit $(5,5-6,5)$. Nilai $\mathrm{pH}$ yang terlalu tinggi dapat menyebabkan iritasi kulit. Tetapi nilai $\mathrm{pH}$ dapat dikontrol dengan penambahan asam misalnya asam sitrat, asam karboksilat dan asam klorida yang dapat menurunkan $\mathrm{pH}$ sabun (Hardian dkk, 2014).

\section{Kadar Air}

Evaluasi kadar air menunjukkan banyakmya kandungan air terdapat dalam sediaan sabun pelembab transparan tersebut. Hasil pengukuran kadar air dapat dilihat pada Tabel 5 dimana kadar air dalam sediaan sabun pelembab tidak memenuhi standar mutu sabun padat (SNI 06-35321994) yaitu maksimal 15\%. Hal ini disebabkan karena adanya air yang digunakan untuk melarutkan zat dan bahanbahan yang digunakan dalam proses pembuatan sabun transparan yang bersifat higroskopis yaitu seperti gliserin, TEA, gula, asam sitrat dan $\mathrm{NaCl}$ (Surilayani dkk, 2019) sehingga kadar air dalam sediaan sabun menjadi tinggi. Efek yang ditimbulkan jika kadar air dalam sediaan sabun tinggi maka sabun akan lebih cepat mengalami penyusutan bobot dan dimensi. Kadar air sabun memiliki korelasi dengan keawetan sabun ketika digunakan, karena sabun tidak mudah larut dalam air (Karo, 2011).

\section{Analisa Asam Lemak Bebas}

Evaluasi bilangan asam lemak bebas dipergunakan untuk mengetahui jumlah asam lemak bebas dalam sediaan sabun pelembab transparan. Hasil yang didapatkan, asam lemak bebas dari sabun 
pelembab transparan pada tiap formula < 2,5\% memenuhi standar mutu sabun padat (SNI 06-3532-1994) dapat dilihat pada Tabel 6. Untuk jumlah bilangan asam lemak tidak boleh terlalu tinggi karena akan memicu ketengikan dan mengurangi umur simpan sabun (Surilayani dkk, 2019).

\section{Analisa Bilangan Penyabunan}

Bilangan penyabunan adalah jumlah mg atau g kalium hidroksida atau natrium hidroksida yang diperlukan untuk menetralkan asam lemak bebas dan menyabunkan ester yang terkandung dalam 1,0 gram atau kilogram zat. Evaluasi ini dilakukan untuk mengetahui sifat fisik lemak atau minyak yang digunakan. Berdasarkan hasil (Tabel 7) yang didapat bilangan penyabunan sabun pelembab memenuhi standar mutu sabun padat (SNI 06-3532-1994) yaitu 1,5-5 gram. Dalam pembuatan sabun transparan, penggunaan $\mathrm{NaOH}$ mempengaruhi jumlah bilangan penyabunan. Semakin banyak $\mathrm{NaOH}$ yang digunakan maka jumlah bilangan penyabunan semakin tinggi. Apabila $\mathrm{NaOH}$ yang ditambahkan terlalu pekat atau jumlahnya berlebih, maka alkali bebas yang tidak berikatan dengan trigliserida atau asam lemak akan terlalu tinggi memberikan pengaruh negatif yaitu iritasi pada kulit. Sebaliknya, apabila $\mathrm{NaOH}$ yang ditambahkan terlalu encer atau jumlahnya terlalu sedikit, maka sabun yang dihasilkan akan mengandung asam lemak bebas yang tinggi. Asam lemak bebas pada sabun mengganggu proses emulsi dan kotoran pada saat sabun digunakan (Kamikaze 2002).

\section{Uji Iritasi}

Uji keamanan atau uji iritasi dari sediaan sabun pelembab transparan selama 3 hari dengan metode uji tempel (patch test). Hasil pengujian menunjukkan tidak adanya respon iritasi pada kulit punggung tangan sukarelawan setelah penggunaan sediaan sabun pelembab transparan dapat dilihat pada Tabel 8 .

\section{Uji Efektivitas (Alat Skin Analyzer)}

Hasil pengujian berupa pengukuran derajat kelembaban (moist), berminyak (oil), dan kekerasan (rough) dapat dilihat pada Tabel 9. Seluruh data yang didapat kemudian diuji secara statistik menggunakan metode uji $\mathrm{t}$ berpasangan dalam tingkatan 95\%. Hasil uji efektivitas (kelembaban, kandungan minyak dan kelembutan) menunjukkan bahwa efek 
melembabkan sudah didapatkan pada formulasi sabun dengan konsentrasi minyak biji bunga matahari $10 \%$ (F2) karena memiliki nilai yang menunjukkan perbedaan bermakna dari pemakaian sediaan sabun sebelum dan sesudah pemakaian $(\mathrm{p} \leq 0,05)$ dapat dilihat pada Tabel 10 .

\section{Uji Kesukaan (Hedonik)}

Uji kesukaan (hedonik) yang dilakukan terhadap formulasi sediaan sabun pelembab transparan yang mengandung minyak biji bunga matahari, menunjukkan metode angket dengan tingkat kepercayaan 95\% $(\alpha=0,05)$. Hasil uji kesukaan menunjukkan F0, F1, F2, dan F3 mempunyai rata-rata yang berbeda dalam uji kesukaan terhadap sediaan (Tabel 11). Urutan tingkat kesukaan terhadap kenyaman sediaan sabun pelembab transparan dari yang tidak disukai sampai yang disukai adalah F0, F1, F3 dan F2 berdasarkan statistik $(\mathrm{p} \leq 0,05)$ yang dapat dilihat pada Tabel 12 . Urutan ini ditentukan berdasarkan kesukaan sukarelawan dari segi kenyamanan penggunaan seperti tidak lengket dikulit, banyaknya busa dan tercium bau yang wangi pada saat digunakan. 


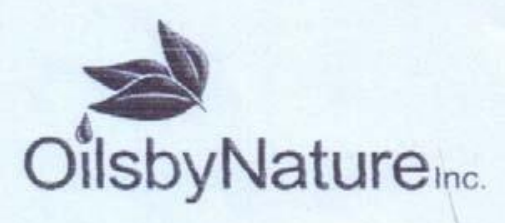

\section{Certificate of Analysis}

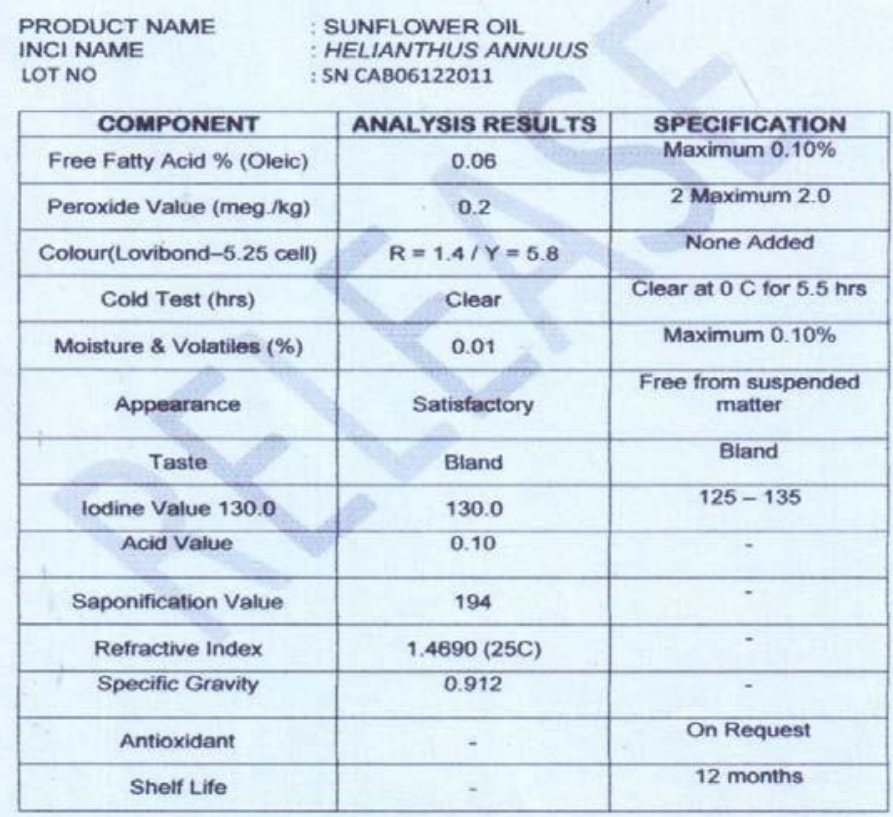

Registration No. IT3734/08 _ VAT No. 4100255670 $30300 \mathrm{OBN}$ industrial Parkway, Suite $\mathrm{E}$, Oldham, $\mathrm{OH} 44139$

Gambar 1. Sertifikat Analisis Minyak Biji Bunga Matahari (Sunflowerseed oil) 
Tabel 1. Formulasi Sediaan Sabun Pelembab Transparan

\begin{tabular}{|c|c|c|c|c|c|}
\hline \multirow{2}{*}{ No } & \multirow{2}{*}{$\begin{array}{l}\text { Nama } \\
\text { Bahan }\end{array}$} & \multicolumn{4}{|c|}{ Jumlah Bahan b/b (\%) } \\
\hline & & F0 & F1 & $\mathrm{F} 2$ & $\mathrm{~F} 3$ \\
\hline 1. & Minyak Biji Bunga Matahari & - & 5 & 10 & 15 \\
\hline 2. & Asam stearat & 8,1 & 8,1 & 8,1 & 8,1 \\
\hline 3. & Oleum cocos & 20 & 15 & 10 & 5 \\
\hline 4. & Natrium hidroksida $(30 \% \mathrm{~b} / \mathrm{v})$ & 21,5 & 21,5 & 21,5 & 21,5 \\
\hline 5. & Gliserin & 15,2 & 15,2 & 15,2 & 15,2 \\
\hline 6. & Sukrosa & 9 & 9 & 9 & 9 \\
\hline 7. & Asam sitrat & 3,5 & 3,5 & 3,5 & 3,5 \\
\hline 8. & Etanol & 18 & 18 & 18 & 18 \\
\hline 9. & BHT & 0,05 & 0,05 & 0,05 & 0,05 \\
\hline 10. & Coco DEA & 3,5 & 3,5 & 3,5 & 3,5 \\
\hline 11. & Air suling & ad 100 & ad 100 & ad 100 & ad 100 \\
\hline 12. & Parfum & qs & qs & qs & qs \\
\hline
\end{tabular}

Tabel 2. Hasil Pemeriksaan Minyak Biji Bunga Matahari

\begin{tabular}{lcc}
\hline Pemeriksaan & $\begin{array}{c}\text { Pustaka (Handbook of } \\
\text { Pharmaceutical } \\
\text { Excipients edisi IV) }\end{array}$ & Hasil Pengamatan \\
\hline $\begin{array}{l}\text { Organoleptis : } \\
\text { - Wujud } \\
\text { - Warna } \\
\quad \text { - Bau }\end{array}$ & $\begin{array}{c}\text { Cairan minyak, berwarna } \\
\text { kuning keemasan dan } \\
\text { berbau khas }\end{array}$ & $\begin{array}{c}\text { Cairan minyak, } \\
\text { berwarna kuning sedikit } \\
\text { keemasan dan berbau } \\
\text { khas lemah }\end{array}$ \\
Berat Jenis (g/mL) & $0,915-0,919$ & 0,9183 \\
Kadar air (\%) & - & 0,303 \\
Bilangan asam & - & 1,6269 \\
Bilangan penyabunan & $188-194$ & 192,284 \\
Bilangan Iodium & $125-140$ & 125,367 \\
Bilangan ester & - & 190,66 \\
\hline
\end{tabular}


Tabel 3. Hasil Pemeriksaan Organoleptis Sediaan Sabun Pelembab Transparan

\begin{tabular}{|c|c|c|c|c|c|c|}
\hline \multirow[t]{2}{*}{ Formula } & \multirow[t]{2}{*}{ Pengamatan } & \multicolumn{5}{|c|}{$\begin{array}{l}\text { Hasil pengamatan organoleptis selama } \\
\text { waktu penyimpanan } \\
\text { (hari) }\end{array}$} \\
\hline & & $\mathbf{0}$ & 7 & 14 & 21 & 28 \\
\hline \multirow{5}{*}{ F0 } & Warna & $\mathrm{P}$ & $\mathrm{P}$ & $\mathrm{PB}$ & PB & $\mathrm{P}$ \\
\hline & & $\mathrm{B}$ & $\mathrm{B}$ & & & $\mathrm{B}$ \\
\hline & $\mathrm{Bau}$ & $\operatorname{Pr}$ & $\operatorname{Pr}$ & $\operatorname{Pr}$ & $\operatorname{Pr}$ & $\operatorname{Pr}$ \\
\hline & Homogenitas & $\mathrm{H}$ & $\mathrm{H}$ & $\mathrm{H}$ & $\mathrm{H}$ & $\mathrm{H}$ \\
\hline & Warna & KMB & $\mathrm{KMB}$ & KMB & $\mathrm{KMB}$ & KMB \\
\hline \multirow[t]{3}{*}{$\mathrm{F} 1$} & $\mathrm{Bau}$ & $\operatorname{Pr}$ & $\operatorname{Pr}$ & $\operatorname{Pr}$ & $\operatorname{Pr}$ & Pr \\
\hline & Homogenitas & $\mathrm{H}$ & $\mathrm{H}$ & $\mathrm{H}$ & $\mathrm{H}$ & $\mathrm{H}$ \\
\hline & Warna & $\mathrm{KB}$ & $\mathrm{KB}$ & KB & KB & $\mathrm{K}$ \\
\hline \multirow[t]{4}{*}{$\mathrm{F} 2$} & & & & & & $\mathrm{~B}$ \\
\hline & $\mathrm{Bau}$ & $\operatorname{Pr}$ & $\operatorname{Pr}$ & $\operatorname{Pr}$ & $\operatorname{Pr}$ & $\operatorname{Pr}$ \\
\hline & Homogenitas & $\mathrm{H}$ & $\mathrm{H}$ & $\mathrm{H}$ & $\mathrm{H}$ & $\mathrm{H}$ \\
\hline & Warna & KTB & KTB & KTB & KTB & KTB \\
\hline \multirow[t]{2}{*}{$\mathrm{F} 3$} & $\mathrm{Bau}$ & $\operatorname{Pr}$ & Pr & $\operatorname{Pr}$ & $\operatorname{Pr}$ & Pr \\
\hline & Homogenitas & $\mathrm{H}$ & $\mathrm{H}$ & $\mathrm{H}$ & $\mathrm{H}$ & $\mathrm{H}$ \\
\hline
\end{tabular}

$\begin{array}{ll}\text { Keterangan: } & \\ \text { PB } & =\text { Putih Bening } \\ \text { KMB = Kuning Muda Bening } \\ \text { KB } & =\text { Kuning Bening } \\ \text { KTB } & =\text { Kuning Tua Bening } \\ \text { Pr } & =\text { Parfum } \\ \text { H } & =\text { Homogen }\end{array}$

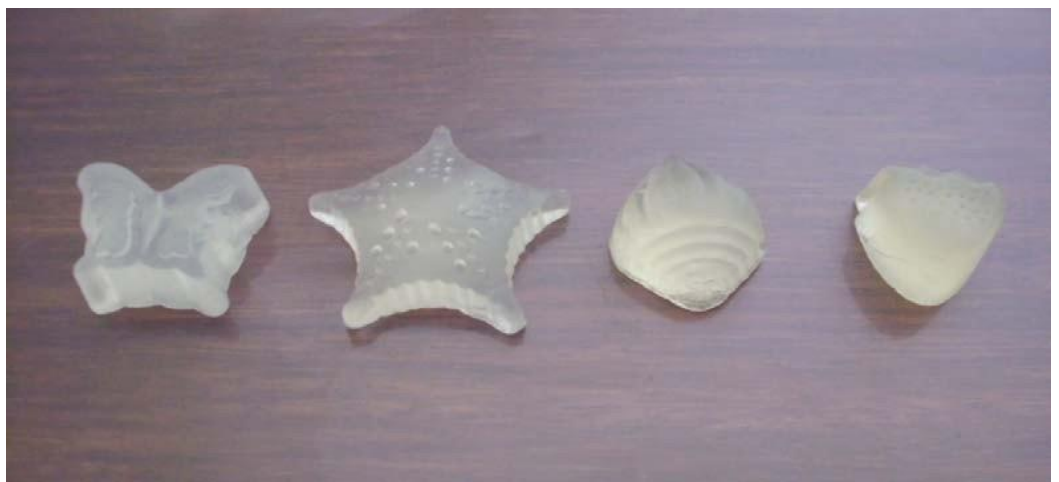

Gambar 2. Sabun Pelembab Transparan Yang Mengandung Minyak Biji Bunga Matahari

Keterangan :

F0 $=$ Formulasi sediaan sabun tanpa minyak biji bunga matahari

$\mathrm{F} 1=$ Formulasi sediaan sabun mengandung minyak biji bunga matahari $5 \%$

$\mathrm{F} 2=$ Formulasi sediaan sabun mengandung minyak biji bunga matahari $10 \%$

$\mathrm{F} 3=$ Formulasi sediaan sabun mengandung minyak biji bunga matahari $15 \%$ 
Pharmacoscript Volume 4 No. 1 Februari 2021

Tabel 4. Hasil Pengukuran pH Sediaan Sabun Pelembab Transparan

\begin{tabular}{|c|c|c|c|c|c|}
\hline \multirow[t]{2}{*}{ Formula } & \multicolumn{5}{|c|}{$\begin{array}{c}\text { pH sediaan sabun pelembab transparan selama waktu } \\
\text { penyimpanan }\end{array}$} \\
\hline & 0 hari & 7 hari & 14 hari & 21 hari & 28 hari \\
\hline $\mathbf{F}_{0}$ & $\begin{array}{c}9,71 \pm \\
0,009\end{array}$ & $\begin{array}{c}9,62 \pm \\
0,026\end{array}$ & $\begin{array}{c}9,54 \pm \\
0,009\end{array}$ & $\begin{array}{c}9,48 \pm \\
0,002\end{array}$ & $\begin{array}{c}9,31 \pm \\
0,016\end{array}$ \\
\hline $\mathbf{F}_{1}$ & $\begin{array}{c}9,60 \pm \\
0,017\end{array}$ & $\begin{array}{c}9,58 \pm \\
0,018\end{array}$ & $\begin{array}{c}9,44 \pm \\
0,008\end{array}$ & $\begin{array}{c}9,38 \pm \\
0,003\end{array}$ & $\begin{array}{c}9,28 \pm \\
0,004\end{array}$ \\
\hline $\mathbf{F}_{2}$ & $\begin{array}{c}9,65 \pm \\
0,013\end{array}$ & $\begin{array}{c}9,52 \pm \\
0,003\end{array}$ & $\begin{array}{l}9,42 \pm \\
0,026\end{array}$ & $\begin{array}{c}9,34 \pm \\
0,005\end{array}$ & $\begin{array}{c}9,23 \pm \\
0,009\end{array}$ \\
\hline $\mathbf{F}_{\mathbf{3}}$ & $\begin{array}{l}9,98 \pm \\
0,010\end{array}$ & $\begin{array}{l}9,82 \pm \\
0,006\end{array}$ & $\begin{array}{l}9,79 \pm \\
0,004\end{array}$ & $\begin{array}{l}9,67 \pm \\
0,006\end{array}$ & $\begin{array}{l}9,56 \pm \\
0,007\end{array}$ \\
\hline
\end{tabular}

Tabel 5. Hasil Pengukuran Kadar Air Sediaan Sabun Pelembab Transparan

\begin{tabular}{cc}
\hline Formula & Kadar Air $(\boldsymbol{\%})$ \\
\hline F0 & $23,96 \pm 0,098$ \\
F1 & $24,50 \pm 0,164$ \\
F2 & $23,79 \pm 0,220$ \\
F3 & $24,09 \pm 0,179$
\end{tabular}

Tabel 6. Hasil Pengukuran Asam Lemak Bebas Sediaan Sabun Pelembab Transparan

\begin{tabular}{cccccc}
\hline Formula & $\begin{array}{c}\text { Kadar Asam } \\
\text { Lemak } \\
\text { Bebas }(\% \mathbf{b} / \mathbf{b})\end{array}$ & I & II & III & Keterangan \\
\hline F0 & $0,5462 \pm 0,021$ & & & 2,5 & M \\
F1 & $0,7325 \pm 0,032$ & $<$ & $<$ & & M \\
F2 & $0,8486 \pm 0,019$ & $2,5 \%$ & $2,5 \%$ & $-7,5 \%$ & M \\
F3 & $0,7339 \pm 0,028$ & & & & M \\
\hline
\end{tabular}


Tabel 7. Hasil Pengukuran Bilangan Penyabunan Sediaan Sabun Pelembab Transparan

\begin{tabular}{ccc}
\hline Formula & Bilangan Penyabunan ( gram ) & Keterangan \\
\hline F0 & $2,7 \pm 0,500$ & $\mathrm{M}$ \\
F1 & $2,03 \pm 0,288$ & $\mathrm{M}$ \\
F2 & $2,53 \pm 0,288$ & $\mathrm{M}$ \\
F3 & $2,2 \pm 0,500$ & $\mathrm{M}$
\end{tabular}

Keterangan: (Pengukuran dilakukan triplo)

$\mathrm{M} \quad=$ Memenuhi Syarat

TM = Tidak Memenuhi Syarat

Tabel 8. Hasil Uji Iritasi Sediaan Sabun Pelembab Transparan Terhadap Sukarelawan

\begin{tabular}{ccccc}
\hline \multirow{2}{*}{ Sukarelawan } & \multicolumn{5}{c}{ Formula Sabun Pelembab Transparan } \\
\cline { 2 - 5 } & F0 & F1 & F2 & F3 \\
\hline 1 & - & - & - & - \\
2 & - & - & - & - \\
3 & - & - & - & - \\
4 & - & - & - & - \\
5 & - & - & - & - \\
6 & - & - & - & - \\
7 & - & - & - & - \\
8 & - & - & - & - \\
9 & - & - & - & - \\
10 & - & - & - & \\
\hline
\end{tabular}

\section{Keterangan :}

- $\quad$ : Tidak timbul iritasi di sekitar daerah kulit tangan pada waktu pengujian keamanan sediaan dengan berbagai formula

$\mathrm{F}_{0}$ : Sabun pelembab transparan tanpa mengandung minyak biji bunga matahari

$\mathrm{F}_{1}$ : Sabun pelembab transparan mengandung minyak biji bunga matahari $5 \%$

$\mathrm{F}_{2}$ : Sabun pelembab transparan mengandung minyak biji bunga matahari $10 \%$

$\mathrm{F}_{3}$ : Sabun pelembab transparan mengandung minyak biji bunga matahari $15 \%$ 
Tabel 9. Hasil Pengukuran Kelembaban, Kandungan Minyak dan Kekasaran Kulit Sediaan Sabun pelembab Transparan Yang Mengandung Minyak Biji Bunga Matahari dengan Menggunakan Skin Analyzer

\begin{tabular}{ccccccc}
\hline \multirow{2}{*}{ Formula } & \multicolumn{2}{c}{ Sebelum Pemakaian } & \multicolumn{3}{c}{ Sesudah Pemakaian } \\
\cline { 2 - 7 } F0 & Moist & Oil & Rough & Moist & Oil & Rough \\
\hline \multirow{4}{*}{ F0 } & -3 & -4 & -3 & -3 & -4 & -3 \\
& -4 & -4 & -4 & -3 & -4 & -3 \\
& -3 & -4 & -3 & -2 & -2 & -2 \\
& -3 & -4 & -3 & -3 & -4 & -3 \\
& -2 & -2 & -2 & -1 & 0 & -1 \\
& -4 & -4 & -4 & -4 & -4 & -4 \\
\hline \multirow{4}{*}{ F1 } & -2 & -2 & -2 & 0 & 1 & 0 \\
& -4 & -4 & -4 & -2 & -2 & -2 \\
& -3 & -4 & -3 & -1 & 0 & -1 \\
& -3 & -4 & -3 & -2 & -2 & -2 \\
& 0 & 1 & 0 & 1 & 4 & 0 \\
& -2 & -2 & -2 & -2 & -2 & -2 \\
\hline \multirow{2}{*}{ F2 } & -3 & -4 & -3 & -2 & -2 & -2 \\
& -2 & -2 & -2 & 0 & 1 & 0 \\
& -2 & -2 & -2 & 1 & 1 & 1 \\
& -2 & -2 & -2 & -1 & 0 & 1 \\
& -3 & -4 & -3 & -1 & 0 & 1 \\
& -2 & -2 & -2 & -1 & -1 & -1 \\
\hline \multirow{6}{*}{ F3 } & -3 & -4 & -3 & 1 & 1 & 1 \\
& -3 & -4 & -3 & 0 & 1 & 0 \\
& -4 & -4 & -4 & -1 & 0 & -1 \\
& -3 & -4 & -4 & -1 & 0 & -1 \\
& -3 & -4 & -3 & 2 & 1 & 2 \\
& -3 & -4 & -3 & 0 & 1 & 0 \\
\hline
\end{tabular}

Keterangan:

Kelembaban

- Kering sekali

-5 sampai -3 (kadar air $<32 \%$ )

- Cenderung kering

:-2 (kadar air 32-33\%)

- Normal

:-1 sampai +1 (kadar air 33-41\%)

- Cenderung lembab

$:+2$

(kadar air 39-41\%)

- Lembab sekali

: +3 sampai $+5($ kadar air $>41 \%)$

Kandungan minyak

- Kering

$:-5$

- Cenderung kering

$:-4$

- Normal

: -3 sampai +3

- Cenderung berminyak

$:+4$

- Berminyak sekali

$:+5$

Kekasaran

- Kasar sekali

: -5 sampai -4

- Cenderung kasar

: -3 sampai -2

- Normal

:-1 sampai +1

- Cenderung lembut

$:+2$ sampai +3

- Lembut

: +4 sampai +5 
Tabel 10. Nilai Signifikan Hasil Uji T-Berpasangan Terhadap Efektivitas Kelembaban, kandungan Minyak dan Kelembutan Sediaan Sabun Pelembab Transparan Yang Mengandung Minyak Biji Bunga Matahari (Sunflowerseed Oil) Terhadap Kulit dengan alat Skin Analyzer

\begin{tabular}{cccc}
\hline \multirow{2}{*}{ Formula } & \multicolumn{3}{c}{ Signifikan } \\
\cline { 2 - 4 } & Kelembaban & $\begin{array}{c}\text { Kadar } \\
\text { minyak }\end{array}$ & $\begin{array}{c}\text { Kelembutan } \\
\text { (Tekstur Kulit) }\end{array}$ \\
\hline F0-F0s & 0,076 & 0,175 & 0,076 \\
F1-F1s & $0,010^{*}$ & $0,030^{*}$ & $0,010^{*}$ \\
F2-F2s & $0,004^{*}$ & $0,002^{*}$ & $0,005^{*}$ \\
F3-F3s & $0,000^{*}$ & $0,000^{*}$ & $0,000^{*}$ \\
\hline
\end{tabular}

Keterangan :

- *): Berbeda secara nyata

- Signifikan

- $\mathrm{P}<0,05$ berbeda secara nyata

- $\quad \mathrm{P}>0,05$ tidak berbeda secara nyata

- $\mathrm{F} 0, \mathrm{~F} 1, \mathrm{~F} 2, \mathrm{~F} 3$

: Sebelum pemakaian sediaan Sabun Pelembab Transparan

- F0s, F1s, F2s, F3s

: Setelah pemakaian sediaan Sabun Pelembab Transparan

Tabel 11. Hasil Uji Kesukaan Sediaan Sabun Pelembab Transparan Yang Mengandung Minyak Biji Bunga Matahari (Sunflowerseed Oil) Terhadap Kulit Punggung Tangan

\begin{tabular}{ccccc}
\hline \multirow{2}{*}{ Sukarelawan } & \multicolumn{5}{c}{$\begin{array}{c}\text { Formula } \\
\text { Sabun }\end{array}$} \\
\cline { 2 - 5 } 1 & F0 & F1 & F2 & F3 \\
\cline { 2 - 5 } 2 & 5 & 3 & 4 & 3 \\
3 & 3 & 5 & 4 & 3 \\
4 & 2 & 3 & 4 & 5 \\
5 & 2 & 3 & 4 & 5 \\
6 & 2 & 3 & 4 & 4 \\
7 & 2 & 3 & 5 & 4 \\
8 & 2 & 3 & 4 & 3 \\
9 & 2 & 4 & 4 & 2 \\
10 & 2 & 4 & 3 & 2 \\
\hline
\end{tabular}

Keterangan :

\begin{tabular}{|c|c|c|}
\hline 5 : sangat suka & $3:$ cukup & \\
\hline 4: suka & 2 : tidak suka & \\
\hline
\end{tabular}

Sampel (Jumlah responden) : 10

F0 : Formula sediaan sabun pelembab transparan yang tidak mengandung minyak biji bunga matahari

F1 : Formula sediaan sabun pelembab transparan dengan konsentrasi minyak biji bunga 
matahari $5 \%$

F2 : Formula sediaan sabun pelembab transparan dengan konsentrasi minyak biji bunga matahari $10 \%$

F3 : Formula sediaan sabun pelembab transparan dengan konsentrasi minyak biji bunga matahari $15 \%$

Tabel 12. Signifikasi Hasil Uji Kesukaan Sukarelawan Terhadap Sediaan Sabun Pelembab Transparan Yang Mengandung Minyak Biji Bunga Matahari (Sunflowerseed Oil)

\begin{tabular}{ccc}
\hline Formula & Formula & Kesukaan \\
\hline \multirow{2}{*}{ F0 } & F1 & $0,009^{*}$ \\
& F2 & $0,000^{*}$ \\
& F3 & $0,003^{*}$ \\
\hline \multirow{2}{*}{ F1 } & F0 & $0,009^{*}$ \\
& F2 & 0,143 \\
& F3 & 0,621 \\
\hline \multirow{2}{*}{ F2 } & F0 & $0,000^{*}$ \\
& F1 & 0,143 \\
& F3 & 0,325 \\
\hline \multirow{2}{*}{ F3 } & F0 & $0,003^{*}$ \\
& F1 & 0,621 \\
& F2 & 0,325 \\
\hline
\end{tabular}

Keterangan :

- * : Berbeda secara nyata

- Signifikan : $\mathrm{P}<0,05$ berbeda secara nyata

$\mathrm{P}>0,05$ tidak berbeda secara nyata

F0 : Formula sediaan sabun pelembab transparan yang tidak mengandung minyak biji bunga matahari

F1 : Formula sediaan sabun pelembab transparan dengan konsentrasi minyak biji bunga matahari $5 \%$

F2 : Formula sediaan sabun pelembab transparan dengan konsentrasi minyak biji bunga matahari $10 \%$

F3 : Formula sediaan sabun pelembab transparan dengan konsentrasi minyak biji bunga matahari $15 \%$ 


\section{KESIMPULAN}

Minyak biji bunga matahari (Sunflowerseed oil) dapat dimanfaatkan sebagai emolien dalam sediaan sabun pelembab transparan. Pengujian organoleptis (warna, bentuk, dan bau), homogenitas, dan $\mathrm{pH}$ sediaan sabun pelembab transparan selama 28 hari tidak mengalami perubahan signifikan pada tiap formula. Hasil evaluasi sediaan sabun pelembab belum seluruhnya memenuhi syarat mutu SNI, namun secara umum sudah baik karena tidak menimbulkan iritasi pada uji sukarelawan. Hasil pengujian efektivitas sediaan terhadap sukarelawan dengan menggunakan skin analyzer menunjukkan bahwa sediaan sabun pelembab transparan yang mengandung minyak biji bunga matahari dengan berbagai konsentrasi (5\%, $10 \%$, dan $15 \%$ ) terbukti memiliki efektivitas melembabkan kulit dan tingkat efektivitasnya yang paling tinggi dalam sediaan sabun pelembab transparan diperoleh pada formula F2 yaitu sabun pelembab transparan yang mengandung minyak biji bunga matahari dengan konsentrasi $10 \%$.

\section{DAFTAR PUSTAKA}

Badan Standarisasi Nasional. (1994). Standar Mutu Sabun Mandi. SNI 06-
3532-1994. Dewan Standarisasi

Nasional. Jakarta

Badan Nasional Indonesia. (1998). SNI 013555-1998. Cara Uji Minyak dan Lemak. Dewan Standarisasi Nasional. Jakarta

Ditjen POM, Depkes RI. (2004). Peraturan Perundang-undangan di Bidang kosmetik. Jakarta. 2.

Ditjen POM, Depkes RI. (1995). Farmakope Indonesia. Edisi IV. Jakarta.

Ditjen POM, Depkes RI. (1985). Formularium Kosmetika Indonesia. Jakarta. 82-105.

Djunda A. (2007). Ilmu Penyakit Ilmu Kulit dan Kelamin. Edisi Kelima. Jakarta : Fakultas Kedokteran Universitas Indonesia. 3-8.

Dr, Prof, Marwali Harahap. (2002). Ilmu penyakit Kulit. Jakarta : Penerbit Hipokrates. 1-3.

Gita L. (2010). Formulasi Sediaan Losion Yang Mengandung Minyak Biji Bunga Matahari (Sunflowerseed oil) Sebagai Emolien [Skripsi]. Cimahi. Jurusan Farmasi FMIPA Universitas Jenderal Achmad Yani. 2. 
Hambali E., Suryani A., Rivai M. (2006). Sabun Pelembab Transparan untuk gift dan kecantikan. Jakarta : Penebar Swadaya.

Hardian K., Ali A., dan Yusmarini. (2014). Evaluasi Mutu Sabun Padat Transparan dari Minyak Goreng Bekas dengan Penambahan SLS (Sodium Lauryl Sulfate) dan Sukrosa. Riau: Jurusan Teknologi Pertanian, Fakultas Pertanian, Universitas Riau.

Hildianti, D.F. (2016). Pemanfaatan Rumput Laut (Eucheuma Cottonii) dalam Pembuatan Sabun Antiseptik. [Skripsi]. Sumatera Selatan: Teknologi Hasil Pertanian, Fakultas Pertanian, Universitas Sriwijaya.

Jellenik, J.S. (1970). Formulation and Function of Cosmetic. New York 324-325. 428-437.

Kamikaze D. (2002). Studi Awal Pembuatan Sabun Menggunakan Campuran Lemak Abdomen Sapi (Tallow) dan Curd Susu Afkir [SKRIPSI]. Bogor: Program Studi Teknologi Hasil Ternak, Jurusan Ilmu Produk Ternak, Fakultas Peternakan, Institut Pertanian Bogor. Hal. 62.
Karo A.Y.K. (2011). Pengaruh Penggunaan Kombinasi Jenis Minyak Terhadap Mutu Sabun Transparan [SKRIPSI]. Bogor: Departemen Teknologi Industri Pertanian, Fakultas Teknologi Pertanian, Institut Pertanian Bogor. Hal. 78.

Ketaren S. (1986). Minyak dan Lemak Pangan. Edisi I. Jakarta : UI Press. 17-34, 39, 45-47, 53.

Raymond C Rowe., J.S. Paul, J.W. Paul. (2003). Handbook of Pharmaceutical Excipients. Fourth Edition. London : Pharmaceutical Press. American Pharmaceutical Association.

Sagarin E. (1966). Cosmetic Science and Technology. $3^{\text {rd }}$ ed. John Wiley \& Sons. New York. 3-5. 213-214.

Sundjaya MR. (2009). Formulasi Sabun Cair Yang Mengandung Minyak Kelapa Murni (VCO) dan Minyak Biji Bunga Matahari [Skripsi]. Bandung: Sekolah Farmasi, Institut Teknologi Bandung.

Surilayani D., Sumarni E., dan Irnawati R. (2019). Karakteristik Mutu Sabun Padat Transparan Rumput Laut (Kappaphycus alvarezii) dengan 
Perbedaan Konsentrasi Gliserin.

Jurnal Perikanan dan Kelautan. Hal. 69-79.

Tranggono R.I dan Latifah F. (2007). Buku Pegangan Ilmu Pengetahuan Kosmetik. Jakarta: PT. Gramedia Pustaka Utama. Hal. 166-167.

Wells, F.V., Lubowe., Irwin I.M.D. (1969). Cosmetics and The Skin. New York: Reinhold Book Corporation, Amsterdam London. 540-541.

Widyasanti A., Farddani, L.C., dan Rohdiana, D. (2016). Pembuatan Sabun Padat Transparan Menggunakan Minyak Kelapa Sawit (Palm Oil) dengan Penambahan Bahan Aktiv Ekstrak Teh Putih (Camellia sinensis). Jurnal Teknik Pertanian Lampung. 5(3): 125-136. 